KAWISTARA

VOLUME 5

No. 2, 17 Agustus 2015

Halaman 99-220

\title{
APPRAISAL KEBERLANJUTAN MULTIDIMENSI PENGGUNAAN LAHAN UNTUK SAWAH DI KARAWANG - JAWA BARAT
}

\author{
Widiatmaka, Khursatul Munibah, dan Santun R.P. Sitorus \\ Departemen Ilmu Tanah dan Sumberdaya Lahan \\ Institut Pertanian Bogor \\ Email: widi.widiatmaka@yahoo.com \\ Wiwin Ambarwulan \\ Badan Informasi Geospasial \\ Irman Firmansyah \\ Program Studi Pengelolaan Sumberdaya Alam dan Lingkungan \\ Institut Pertanian Bogor
}

\begin{abstract}
Indonesian national food sovereignty is very dependent on the supply of rice from paddy fields in Java Island. Various factors influence the farmer's decision to continue using his farm. This study aims to analyze the sustainable use of paddy field, determinant factors and strategies for improving sustainability. The study was conducted in Karawang Regency, one of the centers of rice production in West Java. The methodology used is a multi-dimensional scaling (MDS) using 43 attributes of 5 dimensions (ecological, social, economical, technological and legal and institutional dimension). Against the sensitive attribute analysis resulting from MDS, a prospective analysis was conducted to determine the key factors of sustainability. Priority policies for improving sustainability are developed based on the location of the key factors in the prospective diagram. The research results showed that the land utilization for paddy field in Karawang is actually less sustainable. Increasing the sustainability can be done through intervention and improving performance, preferably on sensitive attributes resulting from leverage analysis, covering 16 attributes. Priority policies is directed in the 5 key factors resulting from prospective analysis. Policies suggested are the tightening of new permits for building, strict implementation of the official spatial land use planning and delineation of agricultural land for sustainable food crops, counseling the community, revitalizing the role of BULOG, provision of subsidies as well as capital assistance to farmers.
\end{abstract}

Keywords: Land use planning, Sustainable development, Agricultural land

\begin{abstract}
ABSTRAK
Kedaulatan pangan nasional sangat bergantung pada penyediaan beras dari lahan sawah di Pulau Jawa. Banyak faktor berpengaruh terhadap keputusan petani untuk melanjutkan penggunaan lahan sawahnya. Penelitian ini bertujuan untuk menganalisis keberlanjutan penggunaan lahan sawah, faktor penentu dan kebijakan peningkatan keberlanjutannya. Penelitian dilakukan di Karawang, salah satu sentra produksi padi Jawa Barat. Metodologi yang digunakan adalah multi-dimensional scalling (MDS) menggunakan 43 atribut dari 5 dimensi (ekologi, sosial, ekonomi, teknologi dan hukum, dan
\end{abstract}


kelembagaan). Terhadap atribut sensitif hasil analisis MDS, dilakukan analisis prospektif untuk menentukan faktor kunci keberlanjutan. Prioritas kebijakan peningkatan keberlanjutan disusun berdasarkan letak faktor kunci pada diagram prospektif. Hasil penelitian menunjukkan bahwa penggunaan lahan untuk sawah di Karawang saat ini kurang berkelanjutan. Peningkatan keberlanjutan penggunaan lahan untuk sawah dapat dilakukan melalui intervensi dan perbaikan kinerja, diutamakan pada atribut sensitif hasil analisis leverage yang meliputi 16 atribut. Prioritas kebijakan diarahkan pada 5 faktor kunci hasil analisis prospektif. Kebijakan yang disarankan berdasarkan faktor kunci tersebut adalah pengetatan terhadap permohonan izin mendirikan bangunan baru, pelaksanaan Rencana Tata Ruang Wilayah kabupaten secara konsisten dan delineasi lahan pertanian pangan berkelanjutan, penyuluhan kepada masyarakat, revitalisasi peran BULOG, pemberian subsidi, dan bantuan modal usaha kepada petani.

Kata kunci: Perencanaan penggunaan lahan, Pembangunan berkelanjutan, Lahan pertanian

\section{PENGANTAR}

Beras merupakan pangan pokok bagi 95\% penduduk Indonesia (Swastika et al., 2007) yang berjumlah lebih dari 237 juta jiwa (BPS, 2010). Dengan tingkat konsumsi mencapai 113 kg/kapita/tahun, kebutuhan beras Indonesia sangat tinggi. Lebih dari 95\% beras dihasilkan dari lahan sawah (Swastika et al., 2007) mengimplikasikan pentingnya lahan sawah. Persoalannya, dari lahan sawah di Indonesia yang seluas 13.835.252 ha (BPS, 2014), seluas 6.467.073 ha atau $46,7 \%$ berada di Pulau Jawa. Dari luas tersebut, lahan sawah di Pulau Jawa memproduksi $52,6 \%$ total produksi padi Indonesia. Angka-angka ini menunjukkan tingginya ketergantungan Indonesia terhadap produksi padi dari lahan sawah di Pulau Jawa.

Dengan luas Pulau Jawa yang kurang dari $7 \%$ luas wilyah Indonesia, artinya lahannya terbatas, ketergantungan ini sangat berisiko bagi kedaulatan pangan nasional. Padahal, berbagai persoalan kompleks dihadapi oleh lahan sawah di Pulau Jawa.
Pulau ini merupakan pulau dengan penduduk terpadat, menyebabkan tekanan yang sangat tinggi terhadap lahan. Kebutuhan infrastruktur seperti perumahan, jalan dan industri telah menyebabkan terjadinya konversi lahan pertanian yang sangat tinggi. Data periode 1989 sampai 2000 menunjukkan bahwa konversi lahan sawah di Pulau Jawa mencapai 1,07 juta ha (Abdurachman et al., 2005). Jika fenomena ini berlanjut, kedaulatan pangan Indonesia terancam, mengingat upaya menurunkan tingkat konsumsi beras misalnya, diperkirakan masih memerlukan waktu lama. Meskipun pemerintah telah menerbitkan UU No. 41 Tahun 2009 tentang Perlindungan Lahan Pertanian Pangan Berkelanjutan, tetapi implementasinya masih jauh dari harapan karena kompleksnya permasalahan. Ini dibuktikan dengan masih terus berlangsungnya konversi lahan sampai saat ini.

Uraian tersebut menunjukkan pentingnya menjaga keberlanjutan penggunaan lahan sawah di Pulau Jawa. Upaya tersebut perlu menempatkan petani sebagai pelaku utama produksi. Petani padi di Jawa merupakan petani berlahan sempit, rata-rata kepemilikan lahannya hanya 0,3 ha/petani (Susilowati et al., 2008). Sempitnya kepemilikan lahan menyebabkan sawah tidak mampu menopang kehidupan petani. Banyak isu kompleks yang menentukan keputusan petani untuk melanjutkan penggunaan lahannya untuk sawah, mulai dari aspek fisik hingga aspek sosial dan ekonomi. Oleh karena itu, upaya menjaga keberlanjutan penggunaan lahan untuk sawah perlu dilihat secara komprehensif dari berbagai aspek, terutama pertimbangan dari sisi petani sebagai pelaku utama produksi.

Di Pulau Jawa, beberapa wilayah secara tradisional merupakan sentra produksi padi. Jawa Barat merupakan salah satu provinsi penghasil beras utama, pada tahun 2012 misalnya menghasilkan 12.083 .162 ton padi (BPS, 2013) atau $17 \%$ dari produksi padi nasional. Salah satu sentra padi penting di Jawa Barat adalah Karawang yang pada tahun 2012 menghasilkan 1.069.012 ton padi, 
atau $10 \%$ produksi padi Jawa Barat (BPS, 2013). Persoalan penggunaan lahan untuk sawah di Karawang hampir sama dengan persoalan yang dihadapi di sentra produksi padi lain di Pulau Jawa, sawah telah secara signifikan berkurang dalam beberapa tahun terakhir. Hasil penelitian Widiatmaka et al. (2013) menunjukkan bahwa lahan sawah di Karawang telah berkurang dari 120.865 ha pada tahun 2000, menjadi 95.926 ha pada tahun 2011. Pengurangan ini berakibat berkurangnya kemampuan wilayah untuk mengekspor beras keluar wilayah, yang jika dihitung pengurangannya mencapai $10 \%$ dalam dekade terakhir. Bagi Karawang, tekanan terhadap lahan lebih berat karena kedekatan lokasinya dengan ibukota negara, Jakarta. Kedekatan wilayah pertanian dengan kota besar memperbesar peluang konversi lahan (Hidajat et al., 2013) karena rendahnya land rent lahan pertanian, dibandingkan dengan penggunaan lahan untuk industri dan pemukiman.

Pertanian umumnya dan penyediaan pangan khususnya dapat berkelanjutan, perlu diterapkan konsep pembangunan berkelanjutan (sustainable development). Pembangunan berkelanjutan adalah pembangunan yang dapat memenuhi kebutuhan saat ini tanpa mengorbankan kemampuan generasi mendatang untuk memenuhi kebutuhan mereka (WCED, 1987). Dalam substansi konsep ini, aspek ekologi, sosial dan ekonomi harus dapat terpenuhi secara simultan agar tidak terjadi trade-off diantara kepentingan yang berbeda (Munasinghe, 1993). Dalam penerapan selanjutnya, aspek pembangunan berkelanjutan tidak hanya sebatas aspek ekologi, ekonomi dan sosial saja, namun dapat bertambah tergantung kebutuhan wilayah yang sedang dikaji. Sebagai contoh, Pitcher et al. (2013) menambahkan dimensi teknologi, etika dan kelembagaan.

Keberlanjutan di bidang pertanian merujuk pada sistem pertanian yang layak secara ekonomi, mampu meningkatkan kualitas hidup petani dan masyarakat pedesaan, dan memperbaiki kualitas lingkungan (European
Commission, 2010; Fauzi dan Oxtavianus, 2014). Pertanian berkelanjutan telah menjadi isu sentral pembangunan berkelanjutan yang menyangkut pengembangan sistem manusia-lingkungan yang kompleks (Pollock et al. 2008; Wu et al., 2010). Dalam hal penggunaan lahan untuk sawah, karena pentingnya perannya sebagai pemasok pangan, penggunaan lahan perlu dilakukan secara bijaksana (Yoon, 2009; Kim et al., 2006).

Banyak metoda telah dikembangkan untuk menilai keberlanjutan (Zhou et al., 2010; Sikdar, 2012). Penilaian dapat dilakukan misalnya melalui evaluasi daur pertumbuhan (life cycle assessment) (Panichelli et al., 2009; Hou et al., 2011), pengambilan keputusan multi-kriteria (Nzila et al., 2012), analisis tapak ekologi (ecological footprint) (Stoeglehner dan Narodoslawsky, 2009) dan lain-lain. Keberlanjutan penggunaan lahan, beberapa metoda empiris diterapkan oleh Braimoh dan Osaki (2010) dan Salazar-Ordonez et al. (2013). Salah satu metoda cepat (appraisal) untuk mengukur keberlanjutan antara lain digunakan oleh Kavanagh (2001) dan Pitcher et al. (2013). Metoda appraisal ini mengukur status keberlanjutan (sustainability status) secara cepat melalui analisis dari berbagai sudut pandang atau dikenal dengan multidimensi, dengan menyertakan parameter atau atribut ekologi, ekonomi, sosial, etika, dan lain-lain.

Kajian bertujuan, yaitu (1) mengukur indeks dan status keberlanjutan multidimensi penggunaan lahan sawah; (2) mengukur indeks keberlanjutan masingmasing dimensi (ekologi, ekonomi, sosial, teknologi, dan hukum serta kelembagaan); (3) mengidentifikasi atribut/avariabel penggunaan lahan sawah yang sensitif terhadap perubahan; dan (4) melihat variabel yang dominan dalam sistem penggunaan lahan sawah untuk menentukan strategi peningkatan keberlanjutannya. Tercapainya tujuan ini di Karawang akan menjadi pembelajaran bagi penjagaan penggunaan lahan untuk sawah di Indonesia guna menjaga kecukupan pangan nasional. 


\section{Wilayah Penelitian}

Penelitian dilakukan di Kabupaten Karawang, Jawa Barat. Secara geografis, wilayah studi terletak antara $107^{\circ} 02^{\prime}-107^{\circ}$ $40^{`} \mathrm{BT}$ dan $5^{\circ} 56^{`}-6^{\circ} 34^{`} \mathrm{LS}$, memanjang ke selatan mulai dari pantai utara Pulau Jawa. Luas wilayah kabupaten adalah 175.327 ha dan secara administratif terdiri dari 30 kecamatan. Wilayah ini memiliki tanah yang subur, terbentuk dari bahan induk vulkanik di bagian selatan dan aluvium di bagian utara. Topografinya relatif datar, kelas lereng datar (0-3\%) mencakup 83,6\% wilayah dan ketinggian $<12 \mathrm{~m}$ di atas permukaan laut mencakup 57,6\% wilayah. Iklimnya tergolong tropika basah, dengan curah hujan tahunan berkisar dari 1.300 sampai $3.200 \mathrm{~mm} /$ tahun. Bulan terbasah adalah Februari, dengan curah hujan 485 $\mathrm{mm} /$ bulan, sedangkan bulan terkering ada lah Juli dengan curah hujan $5 \mathrm{~mm} /$ bulan. Wilayah ini secara tradisional merupakan sentra produksi padi, baik karena kesuburan tanahnya maupun infrastruktur irigasi yang baik

Data primer diperoleh dari survai lapangan, wawancar.a mendalam (depth interview) dan kuesioner. Data primer untuk penghitungan juga diperoleh dari peta yang dihasilkan dari penelitian karena penelitian ini terintegrasi dengan penelitian perubahan penggunaan lahan di Karawang (Widiatmaka et al., 2013; 2014). Responden terdiri dari 2 (dua) kelompok. Kelompok responden pertama adalah responden petani, secara total ada 82 responden yang diambil secara acak, namun ada sampel dari semua kecamatan di Karawang. Jumlah responden ini tidak dimaksudkan untuk mewakili populasi (jumlah) petani secara statistik karena wawancara dengan petani lebih bersifat kualitatif untuk mendalami kriteria "baik" dan "buruk" (Pitcher et al., 2013). Data dari kelompok responden pertama ini digunakan untuk analisis indeks keberlanjutan. Kelompok responden kedua adalah staf pemerintah kabupaten yang terkait dengan penggunaan lahan sawah, yaitu dari Dinas Pertanian, Bappeda, penyuluh pertanian, ketua kelompok tani, dan pemuka masyarakat. Sebanyak 18 orang berpartisipasi dalam Focus Group Discussion (FGD) bagi kelompok kedua ini, yang kemudian diikuti dengan wawancara mendalam, dilaksanakan pada November 2014. Data dari responden kedua digunakan untuk penentuan prioritas kebijakan dalam analisis prospektif, yang metoda analisisnya disajikan pada paragraf "metoda analisis". Data sekunder yang digunakan mencakup hasil penelitian, laporan dan dokumen dari berbagai instansi di Karawang.

Analisis utama yang digunakan adalah analisis keberlanjutan menggunakan metoda multi-dimensional scalling (MDS). Dalam metoda ini, dilakukan proses ordinasi menggunakan teknik ordinasi yang dalam penelitian ini di sebut Rapid Appraisalfor Paddy Field Land Use (Rap-LANDUSE), yang merupakan modifikasi dari Rap-FISH (Kavanagh, 2001; Pitcher et al., 2013). Teknik ordinasi menggunakan parameter yang diukur dengan teknik penskalaan (Fauzi dan Ana, 2005). Pendekatan MDS dipandang cukup stabil dibandingkan beberapa metoda multivariate lain (Pitcher dan Preikshot, 2001; Pitcher et al., 2013).

Tahapan analisis mencakup: (1) penentuan atribut; dalam penelitian ini digunakan 43 atribut pada 5 dimensi yang dianalisis, yaitu 12 atribut dimensi ekologi, 11 atribut dimensi ekonomi, 6 atribut dimensi sosial, 7 atribut dimensi teknologi dan 7 atribut dimensi hukum dan kelembagaan; (2) penilaian setiap atribut dalam skala ordinal (scoring) berdasarkan kriteria keberlanjutan pada setiap dimensi; (3) analisis ordinasi Rap-LANDUSE dengan metoda MDS, menggunakan SPSS untuk menentukan ordinasi dan nilai stress, (4) penilaian indeks dan status keberlanjutan penggunaan lahan untuk sawah, baik secara multidimensi maupun pada setiap dimensi; (5) analisis kepekaan atau sensitivitas (leverage analysis) untuk menentukan atribut yang sensitif mempengaruhi keberlanjutan; (6) analisis Monte Carlo untuk mengecek dan memperhitungkan ketidakpastian; dan (7) analisis prospektif untuk menentukan 
faktor kunci keberlanjutan, yang kemudian digunakan untuk menyusun prioritas kebijakan untuk meningkatka keberlanjutan.

Atribut yang digunakan pada setiap dimensi disajikan pada Tabel 1. Atribut ini diturunkan dari referensi yang membahas pembangunan di pedesaan (UN, 2007; FAO, 2011; Simkova, 2012), maupun dari hasil observasi lapangan. Atribut dalam setiap dimensi dikelaskan berdasarkan kriteria kedalam "baik" dan "buruk" menggunakan konsep dari Fisheries Centre (2002). Setiap atribut yang berada dalam kondisi baik diberi skor 3 (atau 2, tergantung kisaran yang didefinisikan pada setiap atribut), sedangkan yang paling buruk diberi skor 0 , dalam kisaran 0 sampai 3 (atau 2). Skor definitifnya adalah nilai modus, yang kemudian dianalisis untuk menetapkan titik yang mencerminkan posisi relatif keberlanjutan terhadap titik "baik" dan "buruk" menggunakan teknik ordinasi statistik multidimensi. Skor penduga untuk setiap dimensi diekspresikan dalam skala 0\% (buruk) dan 100\% (baik), yang kemudian dikelompokkan dalam 4 kategori: 0-25\% tergolong kategori tidak berkelanjutan, $25,01-50 \%$ tergolong kurang berkelanjutan, $50,01-75 \%$ tergolong berkelanjutan, dan 75,01$100 \%$ tergolong sangat berkelanjutan.

Teknik ordinasi dalam MDS didasarkan pada jarak Eucledian, yang dalam ruang berdimensi $\mathrm{n}$ dapat ditulis sebagai (Pitcher dan Preikshot, 2001):

$$
d=\sqrt{\left(\left|X_{1}-X_{2}\right|^{2}+\left|Y_{1}-Y_{2}\right|^{2}+\left|Z_{1}-Z_{2}\right|^{2}+\cdots\right)}
$$

Konfigurasi atau ordinasi sebuah obyek atau titik dalam MDS kemudian diaproksimasi dengan meregresikan jarak Eucledien (dij) dari titik i ke titik j, dengan titik asal (oij) sebagaimana persamaan berikut (Pitcher dan Preikshot, 2001)

$$
d_{i j}=\alpha+\beta \delta_{i j}+\varepsilon
$$

Teknik yang digunakan untuk meregresikan persamaan tersebut adalah algoritma ALSCAL (Alder et al., 2000). Metoda cocok untuk penskalaan multidimensi dan tersedia hampir di semua perangkat lunak statistik seperti SPSS dan SAS. Metoda ALSCAL mengoptimasi jarak kuadrat (jarak kuadrat $=$ dijk) terhadap kuadrat data (titik awal = oijk), yang dalam tiga dimensi $(i, j, k)$ ditulis dalam formula yang disebut $S$-Stress berikut (Alder et al., 2000):

$$
s=\sqrt{\frac{1}{m} \sum_{k=1}^{m}\left[\frac{\sum_{i} \sum_{j}\left(d_{i j k}^{2}-o_{i j k}^{2}\right)^{2}}{\sum_{i} \sum_{j} o_{i j k}^{4}}\right]}
$$

Jarak kuadrat dibobot dengan jarak Euclidian atau dapat ditulis (Alder et al., 2000):

$$
d_{k}^{2}=\sum_{a=1}^{r} W_{k a}\left(X_{i a}-X_{j a}\right)^{2}
$$

Analisis leverage atau sensitivitas dilakukan untuk melihat atribut yang paling sensitif yang berpengaruh terhadap indeks keberlanjutan pada setiap dimensi. Atribut yang sensitif diperoleh dengan mengubah ordinasi Root Mean Square ( R M S ) $\mathrm{p}$ a d a sumbu $X$ atau skala keberlanjutan. Semakin besar perubahan RMS karena hilangnya atribut tertentu, berarti atribut semakin sensitif perannya bagi keberlanjutan. Atribut yang terletak pada nilai tengah atau lebih besar diambil untuk perumusan kebijakan.

Pada tahap berikutnya, analisis Monte Carlo digunakan untuk menduga pengaruh kesalahan (galat) pada tingkat kepercayaan $95 \%$ atau dengan kata lain, memperhitungkan ketidakpastian (uncertainty). Metoda Monte Carlo menggunakan sekelompok algoritma yang menghubungkan sampel acak untuk mendapatkan hasil numerik; simulasi dilakukan beberapa kali untuk mendapatkan distribusi probabilistik (Robert dan Casella, 2004). Nilai indeks Monte Carlo kemudian diperbandingkan dengan nilai indeks MDS.

Ketepatan (goodness of fit) dalam analisis MDS dicerminkan oleh nilai $S$-stress dan koefisien determinasi $\left(\mathrm{R}^{2}\right)$, yang juga dapat digunakan untuk melihat apakah diperlukan penambahan atribut, atau atribut yang ada telah mencerminkan akurasi setiap dimensi yang dianalisis dikaitkan dengan situasi aktual. Nilai S-stress yang rendah menunjukkan good fit, sedangkan nilai $S$ stress tinggi mencerminkan sebaliknya (Fauzi dan Anna, 2005). Model dikatakan baik atau hampir baik jika hasil analisis menghasilkan nilai $S$-stress kurang dari $0,25(\mathrm{~S}<0,25)$, dan $\mathrm{R}^{2}$ mendekati 1 (100\%) (Pitcher, 2013). 
Tabel 1

Atribut, pengkelasan atribut, dan kriteria "baik" dan "buruk"yang digunakan dalam penelitian ini

\begin{tabular}{|c|c|c|c|c|}
\hline \multirow{2}{*}{\multicolumn{2}{|c|}{ Atribut }} & \multicolumn{2}{|c|}{ Kelas } & \multirow{2}{*}{ Kriteria Baik/Buruk $k^{1)}$} \\
\hline & & Buruk & Baik & \\
\hline \multicolumn{5}{|c|}{ Ekologi } \\
\hline 1 & $\begin{array}{l}\text { Akses jalan ke lahan } \\
\text { sawah }\end{array}$ & 0 & 2 & $\begin{array}{l}\text { Pengukuran pada peta Rupa bumi Indonesia 1:25.000 dan } \\
\text { dan Google Map, ada tidaknya akses jalan ke lahan: (0) } \\
\text { jalan setapak/kecil; (1) jalan setapak sedang; (2) jalan besar } \\
\text { atau pinggir jalan utama (sd: Peta RBI dan Google map) }\end{array}$ \\
\hline 2 & $\begin{array}{l}\text { Pencemaran dari } \\
\text { limbah industri ke } \\
\text { lahan sawah }\end{array}$ & 0 & 2 & $\begin{array}{l}\text { Tercemar; }(1) \text { sedikit tercemar; }(2) \text { tidak tercemar } \\
\text { (sd: wawancara responden petani) }\end{array}$ \\
\hline 3 & $\begin{array}{l}\text { Ketepatan } \\
\text { datangnya musim } \\
\text { hujan setiap tahun }\end{array}$ & 0 & 2 & $\begin{array}{l}\text { Data iklim } 3 \text { tahun terakhir (BMKG), datangnya musim } \\
\text { hujan: (0) bervariasi dalam } 2 \text { bulan; (1) bervariasi dalam } \\
1,5 \text { bulan; (2) selalu jatuh dalam bulan yang sama (sd: } \\
\text { BMKG dan wawancara responden petani) }\end{array}$ \\
\hline 4 & Jaringan irigasi & 0 & 2 & $\begin{array}{l}\text { (0) tidak ada saluran irigasi atau rusak; (1) saluran irigasi } \\
\text { kecil dan kurang baik/agak rusak; (2) saluran irigasi baik } \\
\text { (sd: Peta Jaringan Irigasi, Kementan dan cek lapang) }\end{array}$ \\
\hline 5 & $\begin{array}{l}\text { Pengaturan } \\
\text { frekuensi tanam }\end{array}$ & 0 & 3 & $\begin{array}{l}\text { Data statistik indeks pertanaman: (0) 100\%; (1) } 100- \\
\text { 150\%; (2) 150-200\%; (3) lebih dari 200\% (sd: Karawang } \\
\text { Dalam Angka 2013, BPS) }\end{array}$ \\
\hline 6 & $\begin{array}{l}\text { Penggunaan bibit } \\
\text { padi }\end{array}$ & 0 & 3 & $\begin{array}{l}\text { (0) Kualitas buruk; (1) kualitas sedang; ( } 2) \text { kualitas } \\
\text { baik namun tidak tersertifikasi; ( } 3 \text { ) kualitas baik dan } \\
\text { tersertifikasi (Sumber data: wawancara petani) (sd: } \\
\text { wawancara responden petani) }\end{array}$ \\
\hline 7 & $\begin{array}{l}\text { Tekanan } \\
\text { penggunaan } \\
\text { lahan industri dan } \\
\text { permukiman }\end{array}$ & 0 & 3 & $\begin{array}{l}\text { Kedekatan dengan industri dan kompleks } \\
\text { pemukiman: (0) sangat dekat, } 0-0,5 \mathrm{~km}) ;(1) \text { dekat, } 0,5-1 \\
\mathrm{~km} \text {; (2) sedang, 1-1,5 km; (3) jauh, lebih dari } 2 \mathrm{~km}(\mathrm{sd} \text { : } \\
\text { Google Map dan wawancara responden petani) }\end{array}$ \\
\hline 8 & $\begin{array}{l}\text { Tipe iklim/ } \\
\text { agroklimat } \\
\text { (mengacu pada tipe } \\
\text { iklim di Indonesia) }\end{array}$ & 0 & 3 & $\begin{array}{l}\text { Data iklim } 3 \text { tahun teraklhir: (0) curah hujan }(\mathrm{CH})<1500 \\
\mathrm{~mm} / \mathrm{tahun} ;(1) \mathrm{CH} 1500-2500 \mathrm{~mm} / \mathrm{tahun} ;(2) \mathrm{CH} \\
2.500-3000 \mathrm{~mm} / \mathrm{tahun} \text {; (3) } \mathrm{CH}>3000 \mathrm{~mm} / \mathrm{tahun}(\mathrm{sd} \text { : } \\
\text { data iklim BMKG) }\end{array}$ \\
\hline 9 & $\begin{array}{l}\text { Tingkat kesuburan } \\
\text { lahan sawah }\end{array}$ & 0 & 3 & $\begin{array}{l}\text { Kesesuaian lahan untuk padi: (0) tidak sesuai; (1) } \\
\text { sesuai marginal; (2) sesuai; (3) sangat sesuai (sd: Peta } \\
\text { Kesesuaian Lahan untuk Padi, Widiatmaka et al., 2014) }\end{array}$ \\
\hline 10 & $\begin{array}{l}\text { Tingkat penggunaan } \\
\text { pupuk dan pestisida }\end{array}$ & 0 & 2 & $\begin{array}{l}\text { Penggunaan pupuk dan pestisida: (0) Pemupukan/ } \\
\text { penyemprotan tergantung keuangan keluarga;(1) } \\
\text { pemupukan/penyemprotan dilakukan namun kurang } \\
\text { dari takaran anjuran;(2) pemupukan/ penyemprotan } \\
\text { rutin dan sesuai anjuran (sd: wawancara responden petani) }\end{array}$ \\
\hline 11 & $\begin{array}{l}\text { Pemanfaatan limbah } \\
\text { sawah untuk pakan } \\
\text { ternak }\end{array}$ & 0 & 3 & $\begin{array}{l}\text { Pemanfaatan limbah untuk pakan: (0) tidak; (1) sedikit; } \\
\text { (2) sedang; (3) banyak (sd: wawancara petani) }\end{array}$ \\
\hline 12 & $\begin{array}{l}\text { Pemanfaatan limbah } \\
\text { sawah untuk pupuk } \\
\text { organik }\end{array}$ & 0 & 3 & $\begin{array}{l}\text { Pemanfaatan limbah untuk pupuk: (0) tidak; (1) sedikit; } \\
\text { (2) sedang; (3) banyak (sd: wawancara responden petani) }\end{array}$ \\
\hline
\end{tabular}




\begin{tabular}{|c|c|c|c|c|}
\hline & \multirow{2}{*}{ Atribut } & \multicolumn{2}{|c|}{ Kelas } & \multirow{2}{*}{ Kriteria Baik/Buruk ${ }^{1)}$} \\
\hline & & Buruk & Baik & \\
\hline \multicolumn{5}{|c|}{ Ekonomi } \\
\hline 1 & $\begin{array}{l}\text { Perubahan jumlah } \\
\text { sarana ekonomi } \\
\text { setelah melakukan } \\
\text { usahatani padi }\end{array}$ & 0 & 2 & $\begin{array}{l}\text { (0) Tidak bertambah; (1) bertambah sedikit; (2) selalu } \\
\text { melakukan pembelian sarana baru (sd: wawancara } \\
\text { responden petani) }\end{array}$ \\
\hline 2 & $\begin{array}{l}\text { Kepemilikan } \\
\text { peralatan untuk } \\
\text { usahatani padi }\end{array}$ & 0 & 2 & $\begin{array}{l}\text { (0) Meminjam/menyewa; }(1) \text { sebagian meminjam/ } \\
\text { menyewa; ( } 2 \text { ) semua milik sendiri (sd: wawancara } \\
\text { responden petani) }\end{array}$ \\
\hline 3 & $\begin{array}{l}\text { Simpanan uang } \\
\text { berupa tabungan }\end{array}$ & 0 & 3 & $\begin{array}{l}\text { (0) Tidak punya tabungan; (1) tabungan }<\text { Rp. } 500.000 \text {; } \\
\text { (2) tabungan Rp. 500.000,- s/d Rp. } 1.000 .000,-;(3) \\
\text { tabungan >Rp. } 1.000 .000,- \text { (sd: wawancara responden } \\
\text { petani) }\end{array}$ \\
\hline 4 & $\begin{array}{l}\text { Permodalan } \\
\text { usahatani }\end{array}$ & 0 & 2 & $\begin{array}{l}\text { Modal untuk usahatani: (0) Tidak pernah meminjam; } \\
\text { (1) kadang-kadang meminjam; (2) sering meminjam ( } s \text { : } \\
\text { wawancara responden petani) }\end{array}$ \\
\hline 5 & $\begin{array}{l}\text { Stabilitas harga } \\
\text { gabah }\end{array}$ & 0 & 3 & $\begin{array}{l}\text { Perbedaan harga antara musim panen dan bukan } \\
\text { musim panen: }(0)>40 \% \text {; (1) } 20-40 \% ;(2) 10-20 \% \text {; (3) < } \\
10 \% \text { (sd: Statistik harga BPS 2012-2013) }\end{array}$ \\
\hline 6 & $\begin{array}{l}\text { Subsidi dari } \\
\text { pemerintah }\end{array}$ & 0 & 3 & $\begin{array}{l}\text { Subsidi (termasuk hidden) untuk usahatani padi: } \\
\text { (0) tidak ada; (1) sedikit; (2) sedang; (3) banyak (sd: } \\
\text { wawancara Dinas Pertanian Kabupaten Karawang) }\end{array}$ \\
\hline 7 & $\begin{array}{l}\text { Keuntungan dari } \\
\text { hasil usaha tani padi }\end{array}$ & 0 & 2 & $\begin{array}{l}\text { (0) Hanya untuk makan; (1) dapat untuk penggunaan } \\
\text { lain selain makan; (2) kadang-kadang untuk menambah } \\
\text { modal usaha (sd: wawancara responden petani) }\end{array}$ \\
\hline 8 & $\begin{array}{l}\text { Biaya dari hasil } \\
\text { usaha tani padi } \\
\text { untuk pendidikan } \\
\text { anak }\end{array}$ & 0 & 2 & $\begin{array}{l}\text { (0) Hasil dari usahatani padi tidak cukup, selalu } \\
\text { meminjam; (1) tidak cukup s/d cukup, kadang } \\
\text { meminjam; (2) cukup, tidak pernah meminjam (sd: } \\
\text { wawancara responden petani) }\end{array}$ \\
\hline 9 & $\begin{array}{l}\text { Hasil dari sawah } \\
\text { dibandingkan } \\
\text { keseluruhan pen- } \\
\text { dapatan keluarga }\end{array}$ & 0 & 3 & $\begin{array}{l}\text { (0) } 100 \% \text {; (1) } 60-80 \% \text {; (2) } 40-60 \% \text {; (3) } 40 \% \text { (sd: wawancara } \\
\text { responden petani) }\end{array}$ \\
\hline 10 & $\begin{array}{l}\text { Lembaga permo- } \\
\text { dalan yang dapat } \\
\text { memberikan pin- } \\
\text { jaman modal usaha }\end{array}$ & 0 & 3 & $\begin{array}{l}\text { (0) Tidak ada; (1) ada } 1 \text { buah (misal Bank); ( } 2 \text { ) ada } 2 \\
\text { buah; ( } 3 \text { ) ada } 3 \text { atau lebih (sd: wawancara responden } \\
\text { petani, cek lapangan) }\end{array}$ \\
\hline 11 & $\begin{array}{l}\text { Lembaga pemasaran } \\
\text { yang menampung } \\
\text { hasil }\end{array}$ & 0 & 3 & $\begin{array}{l}\text { (0) Hanya } 1 \text { pasar; (1) ada } 2 \text { pasar; (2) ada } 3 \text { pasar; ( } 3 \text { ) } \\
\text { ada } 4 \text { pasar atau lebih (sd: wawancara responden petani, } \\
\text { cek lapangan) }\end{array}$ \\
\hline \multicolumn{5}{|c|}{ Sosial } \\
\hline 1 & $\begin{array}{l}\text { Mekanisme bagi } \\
\text { hasil tanah garapan }\end{array}$ & 0 & 3 & $\begin{array}{l}\text { Porsi penggarap: }(0)<40 \% \text {; (1) 40-50\%; (2) 50-60\%; (3) } \\
>60 \% \text { (sd: wawancara responden petani) }\end{array}$ \\
\hline 2 & $\begin{array}{l}\text { Budaya gotong } \\
\text { royong dalam } \\
\text { masyarakat }\end{array}$ & 0 & 3 & $\begin{array}{l}\text { Seringnya kerja bersama: (0) jarang; (1) sering; ( } 2) \\
\text { sangat sering; (3) terjadwal (sd: wawancara responden } \\
\text { petani) }\end{array}$ \\
\hline 3 & $\begin{array}{l}\text { Kerukunan hidup } \\
\text { beragama }\end{array}$ & 0 & 3 & $\begin{array}{l}\text { (0) Sering terjadi konflik; (1) pernah terjadi konflik; (2) } \\
\text { tidak pernah terjadi konflik; (3) kerjasama antar umat } \\
\text { sangat baik (sd: wawancara responden petani) }\end{array}$ \\
\hline
\end{tabular}




\begin{tabular}{|c|c|c|c|c|}
\hline & \multirow{2}{*}{ Atribut } & \multicolumn{2}{|c|}{ Kelas } & \multirow{2}{*}{ Kriteria Baik/Buruk ${ }^{1)}$} \\
\hline & & Buruk & Baik & \\
\hline 4 & $\begin{array}{l}\text { Frekuensi kegiatan } \\
\text { penyuluhan dan } \\
\text { pelatihan }\end{array}$ & 0 & 3 & $\begin{array}{l}\text { (0) Tidak pernah; (1) jarang; (2) sering, tidak terjadwal; } \\
\text { (3) terjadwal (sd: wawancara responden petani) }\end{array}$ \\
\hline 5 & $\begin{array}{l}\text { Partisipasi keluarga } \\
\text { dalam kegiatan } \\
\text { usaha tani di lahan } \\
\text { sawah }\end{array}$ & 0 & 2 & $\begin{array}{l}\text { (0) Hanya kepala keluarga bekerja di sawah; }(1) \text { istri } \\
\text { membantu; }(2) \text { istri dan anak membantu (sd: wawancara } \\
\text { responden petani) }\end{array}$ \\
\hline 6 & $\begin{array}{l}\text { Tingkat pendidikan } \\
\text { petani }\end{array}$ & 0 & 3 & $\begin{array}{l}\text { (0) Tidak pernah sekolah; (1) Pernah sekolah SD, tidak } \\
\text { lulus; (2) pernah sekolah SMP, tidak lulus; (3) lulus } \\
\text { SMP atau lebih tinggi (sd: wawancara responden petani) }\end{array}$ \\
\hline \multicolumn{5}{|c|}{ Teknologi } \\
\hline 1 & $\begin{array}{l}\text { Adopsi teknologi } \\
\text { pertanian oleh petani }\end{array}$ & 0 & 3 & $\begin{array}{l}\text { (0) Sangat lambat; (1) lambat; (2) agak cepat; (3) sangat } \\
\text { responsive (sd: wawancara Dinas Pertanian) }\end{array}$ \\
\hline 2 & $\begin{array}{l}\text { Pemupukan spesifik } \\
\text { lokasi }\end{array}$ & 0 & 2 & $\begin{array}{l}\text { (0) Tidak; (1) tergantung keuangan; (2) sudah dilakukan } \\
\text { (sd: wawancara responden petani) }\end{array}$ \\
\hline 3 & $\begin{array}{l}\text { Relevansi teknologi } \\
\text { dengan kebiasaan } \\
\text { petani }\end{array}$ & 0 & 3 & $\begin{array}{l}\text { (0) Sering bertentangan dengan kebiasaan; (1) tidak } \\
\text { pernah bertentangan dengan kebiasaan; (2) relevan } \\
\text { dengan kebiasaan; (3) sangat relevan dengan kebiasaan } \\
\text { (sd: wawancara Dinas Pertanian) }\end{array}$ \\
\hline 4 & $\begin{array}{l}\text { Respon petani ter- } \\
\text { hadap teknologi baru }\end{array}$ & 0 & 2 & $\begin{array}{l}\text { (0) Ragu-ragu; (1) lambat; (2) cepat (sd: wawancara Dinas } \\
\text { Pertanian) }\end{array}$ \\
\hline 5 & $\begin{array}{l}\text { Teknologi yang } \\
\text { disarankan sesuai } \\
\text { dengan kemampuan } \\
\text { petani }\end{array}$ & 0 & 3 & $\begin{array}{l}\text { (0) Tidak sesuai; (1) sedikit sesuai; (2) agak sesuai; ( } 3 \text { ) } \\
\text { sesuai (sd: wawancara Dinas Pertanian) }\end{array}$ \\
\hline 6 & $\begin{array}{l}\text { Basis teknologi yang } \\
\text { tersedia termasuk } \\
\text { yang belum diadopsi }\end{array}$ & 0 & 2 & $\begin{array}{l}\text { (0) Sedikit; (1) sedang; (2) banyak (sd: wawancara Dinas } \\
\text { Pertanian) }\end{array}$ \\
\hline 7 & $\begin{array}{l}\text { Ketersediaan } \\
\text { teknologi pertanian } \\
\text { tepat guna }\end{array}$ & 0 & 2 & $\begin{array}{l}\text { (0) Tidak ada; (1) sedikit; (2) banyak (sd: wawancara } \\
\text { Dinas Pertanian) }\end{array}$ \\
\hline \multicolumn{5}{|c|}{ Hukum dan Kelembagaan } \\
\hline 1 & $\begin{array}{l}\text { Kelembagaan } \\
\text { keuangan mikro dan } \\
\text { koperasi }\end{array}$ & 0 & 2 & $\begin{array}{l}\text { (0) Tidak ada; (1) ada koperasi, namun tidak ada } \\
\text { lembaga keuangan mikro; (2) ada koperasi maupun } \\
\text { lembaga keuangan mikro (sd: wawancara Dinas } \\
\text { Pertanian) }\end{array}$ \\
\hline 2 & $\begin{array}{l}\text { Keberadaan } \\
\text { kelompok tani }\end{array}$ & 0 & 3 & $\begin{array}{l}\text { (0) Tidak ada; (1) ada namun tidak ada aktivitas; }(2) \\
\text { ada, kadang-kadang ada aktivitas; ( } 3 \text { ) ada dan aktif ( } s d \text { : } \\
\text { wawancara responden petani) }\end{array}$ \\
\hline 3 & $\begin{array}{l}\text { Aturan adat/ } \\
\text { kebiasaan }\end{array}$ & 0 & 2 & $\begin{array}{l}\text { (0) Sering dilanggar; (1) ada yang dilanggar; (2) sangat } \\
\text { dipatuhi (sd: wawancara responden petani) }\end{array}$ \\
\hline 4 & $\begin{array}{l}\text { Penyuluhan tentang } \\
\text { pengendalian } \\
\text { konversi lahan }\end{array}$ & 0 & 3 & $\begin{array}{l}\text { (0) Tidak pernah; (1) kadang-kadang; (2) sering; (3) } \\
\text { sangat sering (sd: wawancara responden petani) }\end{array}$ \\
\hline 5 & Penegakan hukum & 0 & 3 & $\begin{array}{l}\text { (0) Banyak pelanggaran hukum tidak ditindak; }(1) \\
\text { ada pelanggaran hukum yang tidak ditindak; }(2) \\
\text { pelanggaran hukum sering ditindak; (3) pelanggaran } \\
\text { hukum selalu ditindak (sd: wawancara responden petani) }\end{array}$ \\
\hline
\end{tabular}




\begin{tabular}{|c|c|c|c|c|}
\hline & \multirow{2}{*}{ Atribut } & \multicolumn{2}{|c|}{ Kelas } & \multirow{2}{*}{ Kriteria Baik/Buruk ${ }^{1)}$} \\
\hline & & Buruk & Baik & \\
\hline 6 & $\begin{array}{l}\text { Konsistensi tataguna } \\
\text { lahan dengan } \\
\text { Rencana Tata Ruang } \\
\text { Wilayah (RTRW) }\end{array}$ & 0 & 3 & $\begin{array}{l}\text { Kesesuaian penggunaan lahan dengan RTRW: (0) } \\
<50 \% \text {, (1) } 50-60 \% \text {; (2) } 60-70 \% ;(3)>70 \% \text { (sd: overlay } \\
\text { citra Landsat TM - Peta Pola Ruang RTRW) (sd: overlay } \\
\text { peta, GIS) }\end{array}$ \\
\hline 7 & $\begin{array}{l}\text { Kejelasan Rencana } \\
\text { Umum Tata Ruang } \\
\text { (RUTR) }\end{array}$ & 0 & 3 & $\begin{array}{l}\text { (0) Tidak dimengerti; (1) agak mengerti; (2) mengerti; } \\
\text { (3) sangat jelas (sd: wawancara responden petani) }\end{array}$ \\
\hline
\end{tabular}

1) Keterangan: $\mathrm{sd}=$ sumber data

Atribut yang sensitif berdasarkan hasil analisis MDS kemudian dianalisis meng gunakan analisis prospektif, untuk menetapkan faktor kunci untuk perumusan kebijakan, didasarkan pada tingkat ketergantungan dari output (Bourgeois dan Jesus, 2004). Untuk melihat pengaruh antar faktor dalam sistem, digunakan matriks (Gambar 1a) Expert atau stakeholder terlibat secara langsung dalam proses penentuan pengaruh, dengan mengisi matriks dengan nilai $0-3$.

Untuk menentukan faktor kunci, digunakan program analisis prospektif yang akan menunjukkan tingkat pengaruh dan ketergantungan faktor dalam sistem (Gambar 1b).

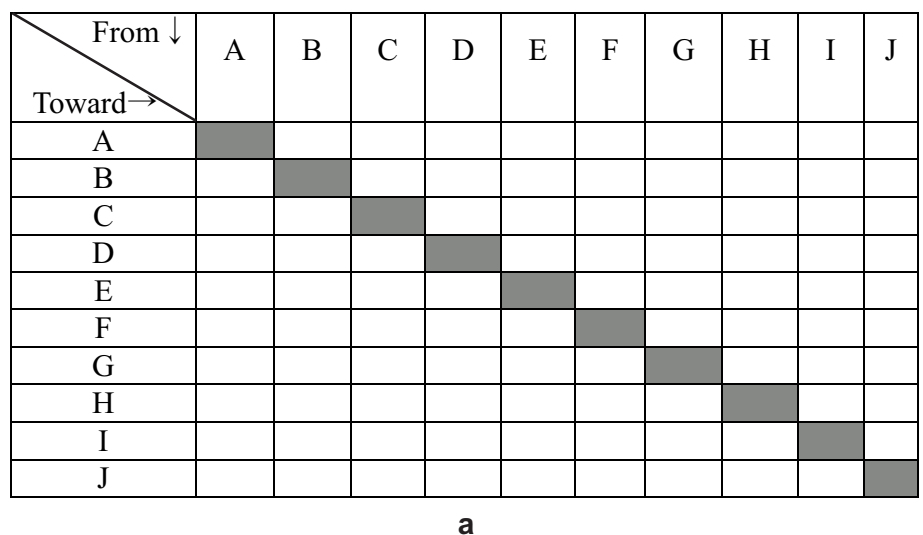

Sumber : Godet(1999)

A-J: Kepentingan faktor dalam sistem Skor: 0 (tidak ada pengaruh); 1 (berpengaruh kecil); 2:berpengaruh sedang; 3 : berpengaruh kuat

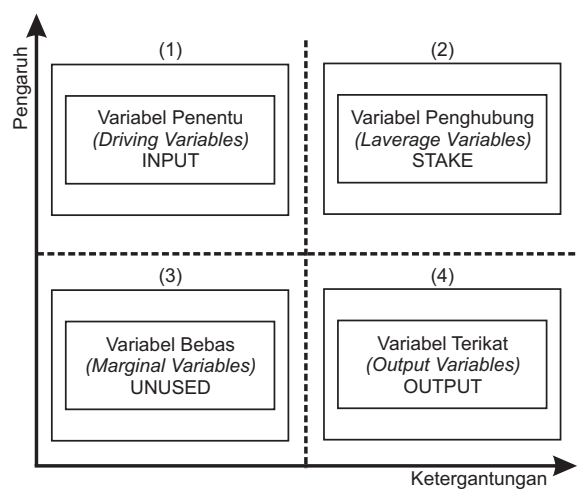

b

Sumber : Hartrisari (2007), Bourgeois dan Jesus (2004)

Gambar 1

Isian dan interpretasi analisis keberlanjutan: (a) matriks isian untuk penetapan pengaruh langsung antar faktor, (b) tingkat pengaruh dan ketergantungan antar faktor

Dalam Gambar 1b, kuadran (1) berisi variabel penentu (driving variable), yang memiliki pengaruh kuat namun ketergantungan yang kurang kuat, sehingga dapat dikategorikan sebagai variabel yang kuat (powerfull) dalam sistem. Pada kuadran (2), terdapat variabel penghubung (leverage variable), yang memiliki pengaruh kuat dengan ketergantungan yang juga kuat, variabel ini juga dikategorikan powerfull. Pada kuadran (3), terdapat variabel bebas (marginal variables) yang memiliki pengaruh maupun ketergantungan kecil, sehingga bebas di dalam sistem. Pada kuadran (4), terdapat variabel terikat (output variables), yang memiliki pengaruh kecil namun ketergantungan terhadap sistem tinggi. 


\section{PEMBAHASAN}

\section{Keberlanjutan Multidimensi}

Hasil analisis menggunakan RapLANDUSE disajikan dalam bentuk kitediagram (Gambar 2). Indeks keberlanjutan dimensi ekologi, ekonomi dan hukum dan kelembagaan tergolong kurang berkelanjutan; indeks keberlanjutan dimensi sosial dan dimensi teknologi tergolong berkelanjutan. Indeks multidimensi keseluruh an penggunaan lahan untuk sawah di Karawang adalah 46,54 atau kurang berkelanjutan. Status keberlanjutan multidimensi yang kurang berkelanjutan disebabkan relatif rendahnya indeks masing-masing dimensi. Hanya dimensi sosial dan dimensi teknologi yang indeks keberlanjutannya relatif baik, sementara tiga dimensi lain memiliki indeks keberlanjutan yang kurang baik. Untuk meningkatkan indeks keberlanjutan, intervensi dapat dilakukan pada atribut yang sensitif.

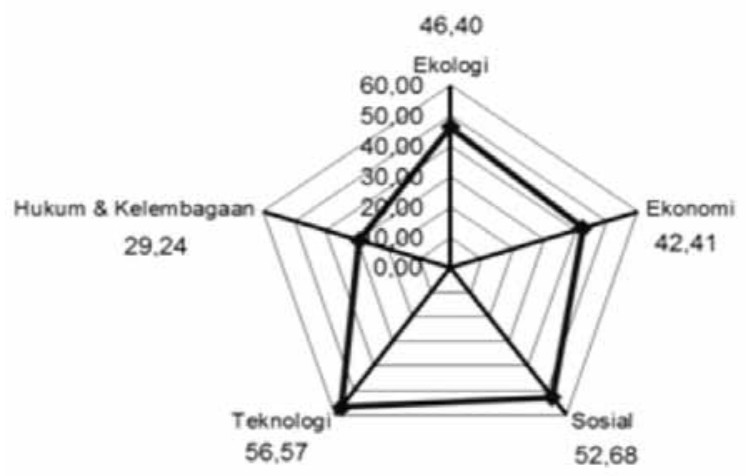

Gambar 2

Indeks Keberlanjutan Penggunaan Lahan untuk Sawah di Karawang

Hasil analisis keberlanjutan pada masing-masing dimensi, ekologi, ekonomi, sosial, teknologi dafn hukum dan kelembagaan penggunaan lahan untuk sawah di Karawang berturut-turut disajikan pada Gambar 3 (a sampai e).

Pada dimensi ekologi bahwa analisis terhadap 12atribut menghasilkan nilai indeks keberlanjutan 46, 40 yang berarti kurang berkelanjutan, indeks terletak di antara nilai
25-50 (Gambar 3a). Hal ini menunjukkan bahwa kondisi ekologi penggunaan lahan untuk sawah di Kabupaten Karawang saat ini kurang mendukung untuk terus dilakukannya penggunaan lahan untuk sawah. Berdasarkan analisis leverage terhadap atribut dimensi ekologi (Gambar 4), 4 (empat) atribut yang paling sensitif terhadap tingkat keberlanjutan dari dimensi ekologi adalah tekanan penggunaan lahan untuk industri dan pemukiman ( $\mathrm{RMS}=2,0878)$, akurasi datangnya musim hujan (RMS = $2,4861$ ), saluran irigasi ( $R M S=2,4435)$, dan frekuensi penanaman (RMS $=2,6765$ ). Intervensi terhadap ke-4 atribut sensitif ini akan lebih berpengaruh terhadap kenaikan indeks keberlanjutan dari dimensi ekologi, dibandingkan intervensi terhadap atribut lain.

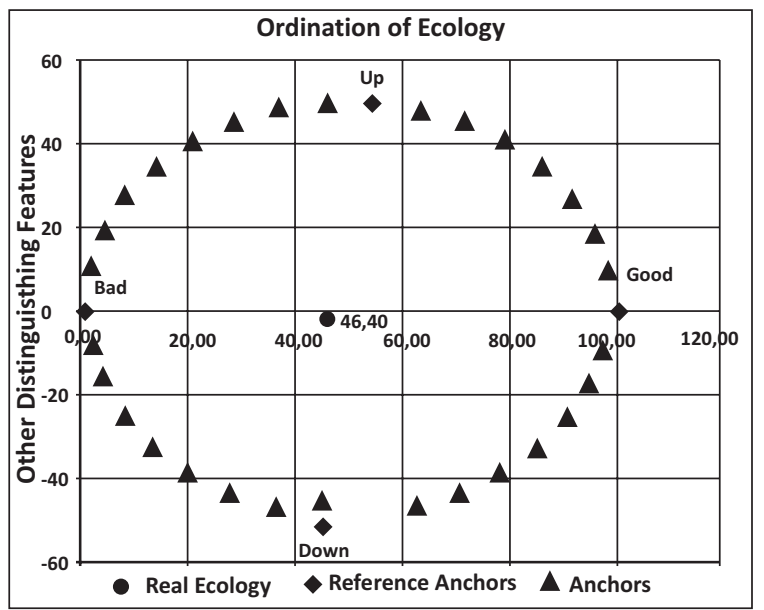

(a)

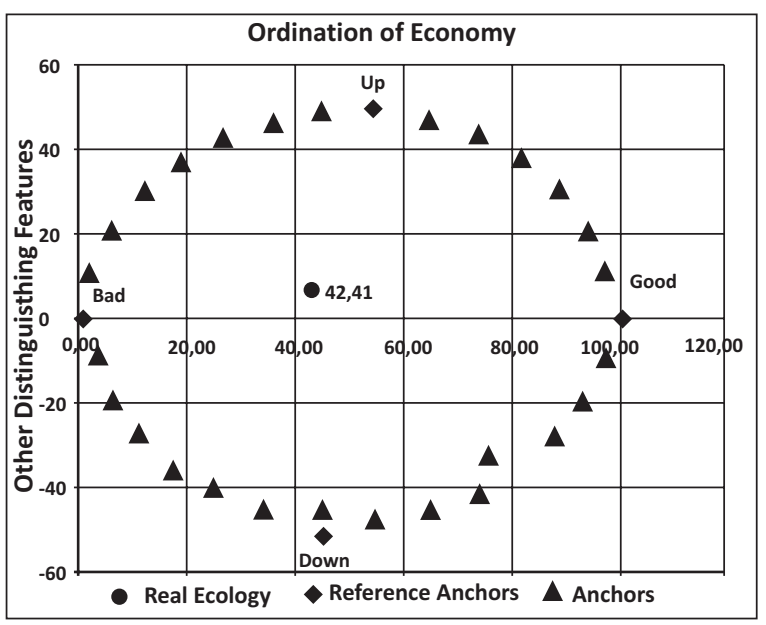

(b) 


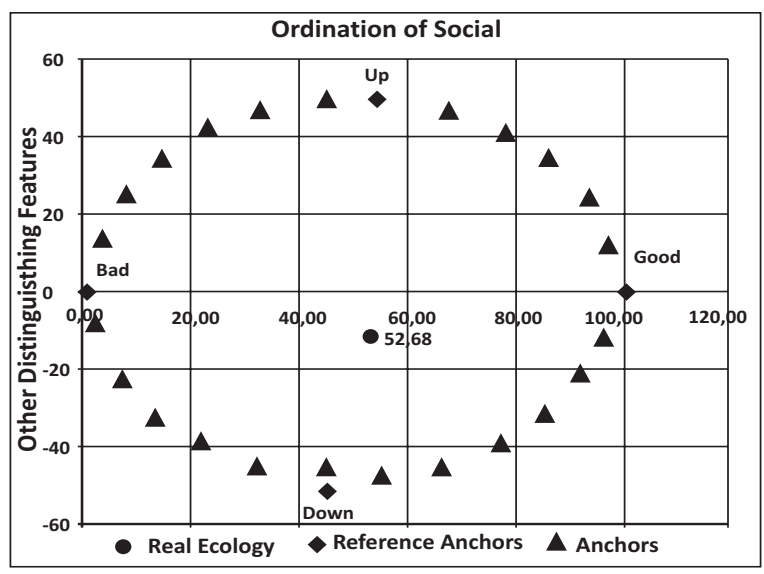

(c)

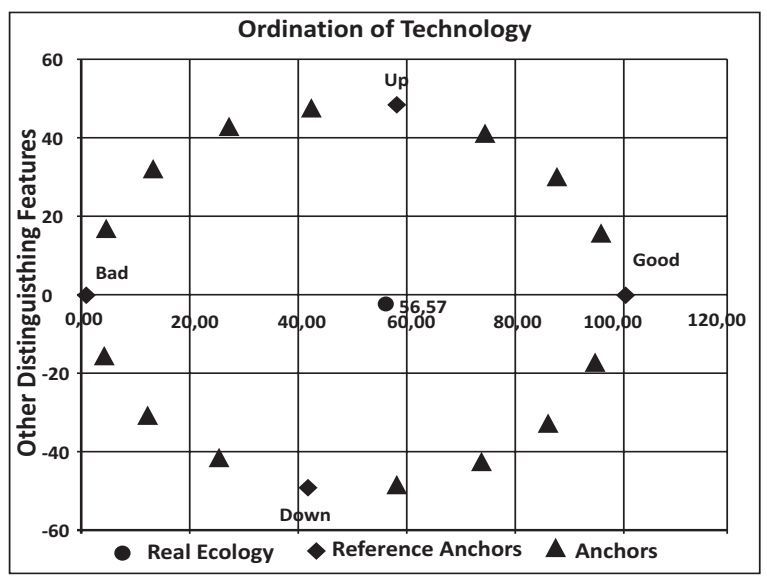

(d)

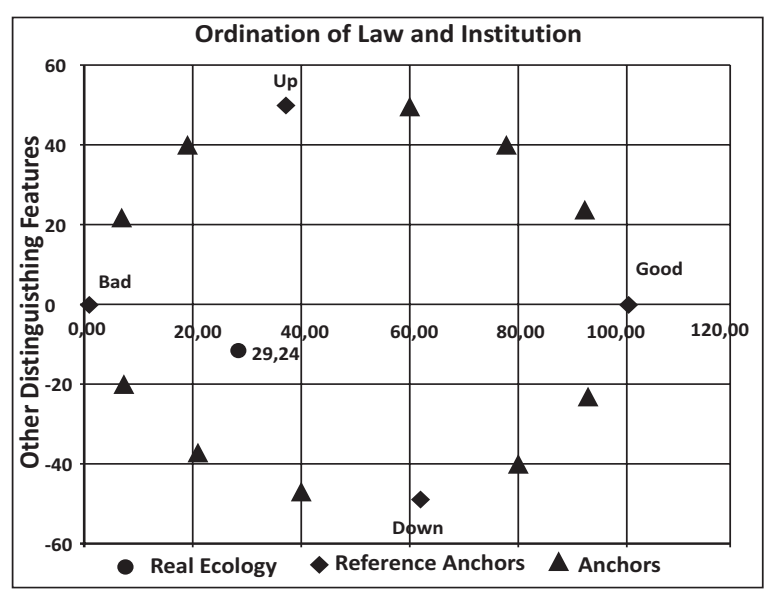

(e)

Gambar 3

Indeks Keberlanjutan dan Atribut Sensitif (leverage) Penggunaan Lahan untuk Sawah di Karawang pada Masing-Masing Dimensi: (a) Ekologi, (b) Ekonomi, (c) Sosial, (d) Teknologi, dan (e) Hukum dan Kelembagaan
Analisis terhadap 11 atribut dari dimensi ekonomi menghasilkan nilai indeks keberlanjutan 42,41, yang berarti kurang berkelanjutan (Gambar 3b). Hal ini mengandung pengertian bahwa fungsi sumberdaya lahan sawah di Kabupaten Karawang lebih kecil nilai ekonominya (land rent) dibandingkan dengan nilai ekonomi penggunaan lahan lain. Tiga atribut yang paling sensitif untuk peningkatan keberlanjutan dari dimensi ekonomi (Gambar 4) meliputi stabilitas harga (RMS $=3,0179$ ), pendapatan dari usaha tani padi (RMS = 2,9668), dan kepemilikan tabungan (RMS = 2,1191).

Hasil analisis terhadap enam atribut menunjukkan bahwa nilai indeks keberlanjutan dimensi sosial sebesar 52,68 yang berarti cukup berkelanjutan (Gambar 3c). Berdasarkan analisis leverage terhadap atribut sosial, atribut yang dinilai paling sensitif terhadap tingkat keberlanjutan dari dimensi sosial adalah partisipasi keluarga dalam usahatani padi (RMS = 2,9902) (Gambar 4). Relatif baiknya kehidupan bermasyarakat di antara sesama petani, rukunnya kehidupan bertetangga dan tingkat partisipasi masyarakat yang relatif baik menyebabkan dimensi sosial cukup berkelanjutan. Hal ini dapat dijadikan modal sosial untuk lebih meningkatkan keberlanjutan dimensi sosial.

Hasil analisis 7 (tujuh) atribut menghasilkan nilai indeks keberlanjutan dimensi teknologi sebesar 56,57 yang berarti cukup berkelanjutan (Gambar 3d). Berdasarkan analisis leverage terhadap atribut teknologi, atribut yang sensitif terhadap keberlanjutan dari dimensi teknologi adalah ketersediaan teknologi tepat guna (RMS $=0,8718$ ) (Gambar 4). Cukup berkelanjutannya dimensi teknologi antara lain didukung oleh ketersediaan berbagai teknologi pertanian padi, antara lain di Badan Litbang Kementerian Pertanian (Balitbangtan, 2015). Akan tetapi, dewasa ini belum semua teknologi yang tersedia telah diterapkan secara praktikal pada tingkat petani, sehingga kemungkinan untuk peningkatan keberlanjutan dari sisi teknologi masih terbuka. 
Hasil analisis terhadap 7 (tujuh) atribut menghasilkan nilai indeks keberlanjutan dimensi hukum dan kelembagaan sebesar 29,24 yang berarti kurang berkelanjutan (Gambar 3e). Berdasarkan analisis leverage terhadap atribut kelembagaan diperoleh atribut yang sensitif terhadap tingkat keberlanjutan dari dimensi kelembagaan (Gambar 4) adalah (i) penegakan hukum (RMS = 5,5696), (ii) konsistensi penggunaan lahan dengan Rencana Tata Ruang Wilayah $(\mathrm{RTRW}) \quad(\mathrm{RMS}=4,7496), \quad$ (iii) lembaga keuangan dan koperasi $(\mathrm{RMS}=4,3161)$, (iv) kelompok tani (RMS= 4,1322), (v) kebiasaan dan adat istiadat (RMS $=3,9404)$, (vi) kejelasan RTRW (RMS= 3,8530), dan (vii) penyuluhan tentang konversi lahan (RMS=3,6519). Sangat rendahnya dimensi hukum dan kelembagaan di sektor pertanian tampaknya merupakan cerminan dari kehidupan bernegara bidang hukum dan kelembagaan di berbagai sektor lain, yang di Indonesia masih sangat lemah, tercermin pula dari berbagai fakta peristiwa hukum dan kelembagaan akhir-akhir ini yang cukup memprihatinkan (Kompas, 30 Januari 2015).

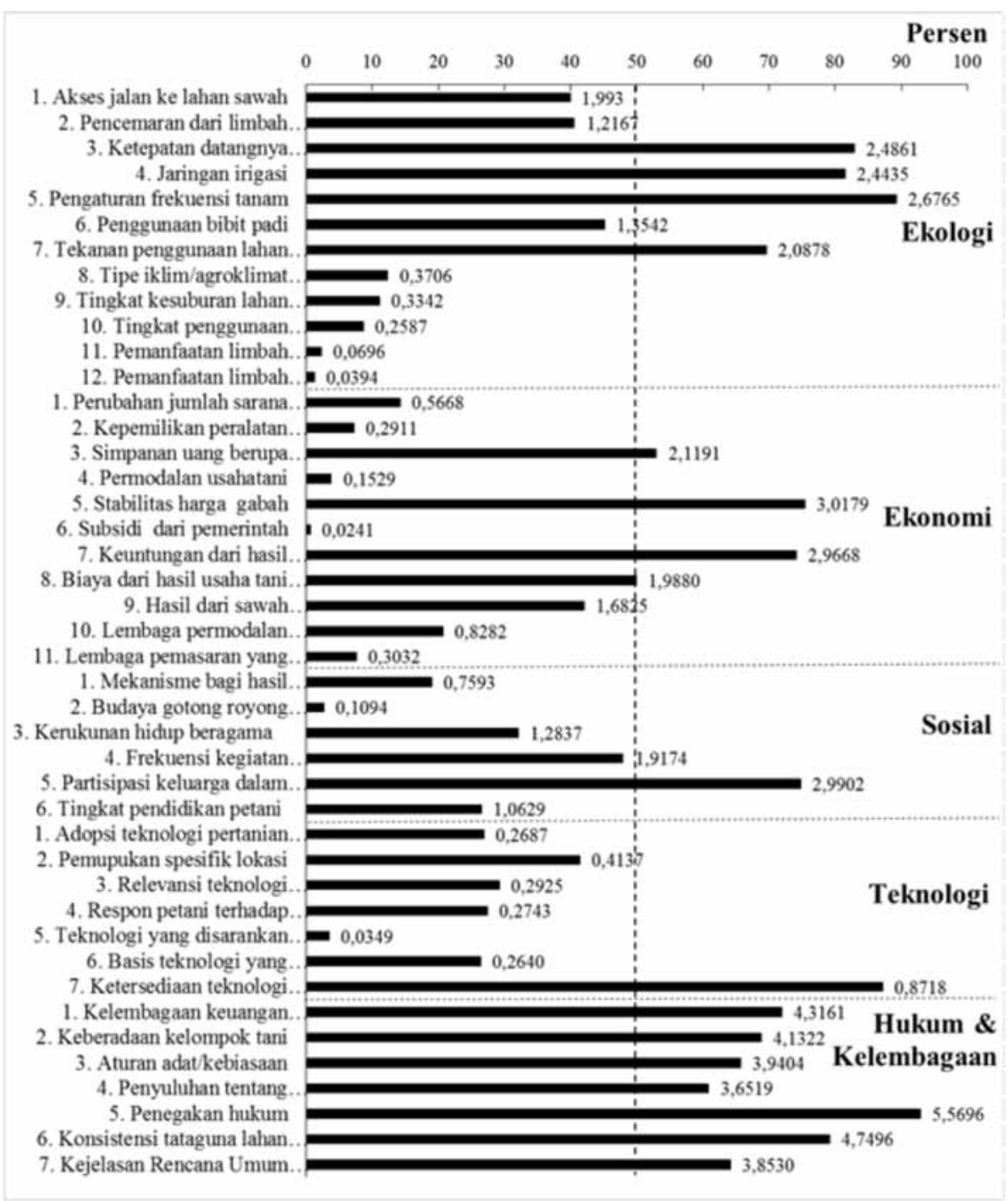

Gambar 4

Faktor-Faktor Sensitif Mempengaruhi Keberlanjutan Penggunaan Lahan untuk Sawah di Karawang pada ke-5 Dimensi Keberlanjutan

Keterangan Gambar: (i) sumbu X (0-100\%): persen RMS atribut pada masing-masing dimensi, persentase tidak untuk dibandingkan antar dimensi; (ii) angka-angka menunjukkan RMS masing-masing atribut di dalam setiap dimensi, tidak untuk dibandingkan antar dimensi; (iii) keterangan atribut pada sumbu $Y$ diringkas (dengan titik-titik) untuk alasan kejelasan gambar, penamaan atribut selengkapnya merujuk pada Tabel 1. 
Dengan demikian, hasil analisis menunjukkan bahwa pada kelima dimensi (ekologi, ekonomi, sosial, teknologi, dan hukum \& kelembagaan) terdapat atribut yang berperan sebagai faktor sensitif (leverage factor) yang berada di setiap dimensi secara parsial (Tabel 2). Untuk meningkatkan status keberlanjutan penggunaan lahan untuk sawah di wilayah penelitian, maka terhadap ke-16 atribut tersebut perlu dilakukan intervensi. Untuk melakukan intervensi terhadap atribut sebanyak itu, tentu diperlukan pemrioritasan. Untuk itu, analisis prospektif akan membantu memilih atribut kunci yang perlu diprioritaskan penanganannya.

Tabel 2.

Atribut Sensitif Dimensi Keberlanjutan Penggunaan Lahan untuk Sawah di Karawang

\begin{tabular}{|c|c|c|c|}
\hline No. & $\begin{array}{c}\text { Dimensi } \\
\text { keberlanjutan }\end{array}$ & Atribut sensitive & $\begin{array}{l}\text { Nilai } \\
\text { RMS }\end{array}$ \\
\hline 1. & Dimensi Ekologi & $\begin{array}{l}\text { 1. Tekanan penggunaan lahan industri dan permukiman } \\
\text { 2. Ketepatan datangnya musim hujan setiap tahun } \\
\text { 3. Jaringan irigasi } \\
\text { 4. Pengaturan frekuensi tanam }\end{array}$ & $\begin{array}{l}2,0878 \\
2,4861 \\
2,4435 \\
2,6765\end{array}$ \\
\hline 2. & Dimensi Ekonomi & $\begin{array}{l}\text { 1. Stabilitas harga gabah } \\
\text { 2. Keuntungan dari hasil usaha tani padi } \\
\text { 3. Simpanan uang berupa tabungan }\end{array}$ & $\begin{array}{l}3,0179 \\
2,9668 \\
2,1191\end{array}$ \\
\hline 3. & Dimensi Sosial & 1. Partisipasi keluarga dalam kegiatan usahatani di lahan sawah & 2,9902 \\
\hline 4. & Dimensi Teknologi & 1. Ketersediaan teknologi pertanian tepat guna & 0,8718 \\
\hline 5. & $\begin{array}{l}\text { Dimensi Hukum } \\
\text { dan Kelembagaan }\end{array}$ & $\begin{array}{l}\text { 1. Penegakan hukum } \\
\text { 2. Konsistensi tataguna lahan dengan Rencana Tata Ruang } \\
\text { Wilayah (RTRW) } \\
\text { 3. Kelembagaan keuangan mikro dan koperasi } \\
\text { 4. Keberadaan kelompok tani } \\
\text { 5. Aturan adat/kebiasaan } \\
\text { 6. Kejelasan Rencana Umum Tata Ruang (RUTR) } \\
\text { 7. Penyuluhan tentang pengendalian konversi lahan }\end{array}$ & $\begin{array}{l}5,5696 \\
4,7496 \\
4,3161 \\
4,1322 \\
3,9404 \\
3,8530 \\
3,6519\end{array}$ \\
\hline
\end{tabular}

Pembandingan hasil analisis MDS dengan hasil analisis Monte Carlo pada taraf kepercayaan 95\% (Tabel 3) menunjukkan selisih nilai yang sangat kecil $(0,25 \%)$, atau tidak lebih dari 5\%. Dengan kata lain, tingkat kepercayaan terhadap indeks total (multidimensi) ter hadap indeks setiap dimensi lebih dari 95\%. Ini berarti bahwa model analisis MDS yang dihasilkan memadai untuk menduga keberlanjutan penggunaan lahan untuk sawah di Karawang. Beda nilai Tabel 3

Hasil Analisis Monte Carlo untuk Nilai Indeks Keberlanjutan Multidimensi dan Masing-Masing Dimensi pada Selang Kepercayaan 95\%

\begin{tabular}{|c|c|c|c|c|c|c|c|}
\hline Status Indeks & MDS & Monte Carlo & Perbedaan & Status Indeks & MDS & Monte Carlo & Perbedaan \\
\hline Ekologi & 46,40 & 46,35 & 0,05 & Hukum dan & & & \\
\hline Ekonomi & 42,41 & 42,90 & 0,49 & Kelembagaan & 29,24 & 29,42 & 0,18 \\
\hline Sosial & 52,68 & 52,45 & 0,23 & Multidimensi & 46,54 & 46,79 & 0,25 \\
\hline Teknologi & 56,57 & 56,15 & 0,42 & & & & \\
\hline
\end{tabular}

yang kecil juga menunjukkan bahwa pengaruh kesalahan terhadap pembuatan skor pada setiap atribut, kesalahan yang diakibatkan karena kurangnya pemahaman, perbedaan opini, atau penilaian dari peneliti yang saling berbeda, kesalahan pemasukan data atau data yang hilang, dan kesalahan posedur yang dapat mempengaruhi stabilitas proses analisis MDS, relatif kecil. Proses analisis data yang dilakukan secara berulang juga relatif stabil (Fauzi et al., 2005; Pitcher et al., 2013). 


\section{Ketepatan Analisis (Goodness of fit)}

Dari hasil analisis Rap-LANDUSE diperoleh koefisien determinasi $\left(\mathrm{R}^{2}\right)$ antara 94,08\%-95,28\% atau lebih besar dari $80 \%$,bahkan mendekati 100\%.Ini berarti model pendugaan indeks keberlanjutan baik dan memadai digunakan (Kavanagh, 2001; Pitcher et al., 2013), nilai S-stress antara 0,14-
0,16 . Nilai koefisien determinasi ini mendekati nilai $95-100 \%$ dan nilai S-stress yang lebih kecil dari 0,25 menunjukkan model analisis MDS yang diperoleh memiliki ketepatan yang tinggi (goodness of fit) (Fisheries.com, 1999). Nilai S-stress dan koefisien determinasi hasil analisis Rap-LANDUSE disajikan pada Tabel 4.

Tabel 4

Beberapa Parameter Statistik Hasil Analisis Keberlanjutan Penggunaan Lahan untuk Sawah di Karawang

\begin{tabular}{lllllll}
\hline & \multicolumn{1}{c}{ Ekologi } & \multicolumn{1}{c}{ Ekonomi } & Sosial & \multicolumn{1}{c}{ Teknologi } & $\begin{array}{c}\text { Hukum dan } \\
\text { Kelembagaan }\end{array}$ & Multidimensi \\
\hline Stress & 0,133089 & 0,132271 & 0,134549 & 0,149295 & 0,143514 & 0,128921 \\
RMS & 0,954361 & 0,951441 & 0,954387 & 0,947910 & 0,949439 & 0,957894 \\
$\%$ Analisis & $46,40 \%$ & $42,41 \%$ & $52,68 \%$ & $56,57 \%$ & $29,24 \%$ & $46,54 \%$ \\
\hline
\end{tabular}

Faktor Kunci Keberlanjutan dan Strategi Peningkatan Keberlanjutan

Analisis prospektif yang dilakukan terhadap atribut sensitif menghasilkan diagram prospektif (Gambar 5). Berdasarkan letak atribut sensitif dalam diagram tersebut, selanjutnya diperoleh faktor kunci untuk penyusunan prioritas penanganan untuk meningkatkan keberlanjutan penggunaan lahan untuk sawah. Berdasarkan diagram tersebut, 3 atribut yang memiliki pengaruh maupun ketergantungan kuat sebagai berikut: (1) tekanan dari penggunaan lahan untuk industri dan pemukiman, (2) penegakan hukum, dan (3) penyuluhan untuk mengontrol konversi lahan. Sementara itu, prioritas kedua adalah pada atribut yang memiliki pengaruh kuat, walaupun tingkat ketergantungannya relatif lebih rendah, meliputi: (1) stabilitas harga dan (2) pendapatan dari usaha tani padi. Berdasarkan atribut kunci inilah kebijakan prioritas dapat disusun untuk meningkatkan keberlanjutan penggunaan lahan sawah (Tabel 5).

Kelihatannya, faktor kunci pada kuadran pertama saling terkait. Aspek tekanan dari penggunaan lahan oleh industri dan pemukiman, penegakan hukum dan pemahaman masyarakat tentang konversi lahan merupakan masalah yang saling berkaitan. Dalam hal tekanan oleh penggunaan lahan industri dan pemukiman, faktor ini merupakan faktor eksternal yang sangat sulit ditolak, bahkan semakin lama akan semakin intensif bagi Karawang sehubungan dekatnya lokasi dengan ibukota Jakarta dan kepentingan komersial yang semakin meningkat. Kawasan-kawasan industri yang telah ada saat ini bahkan diperkirakan akan semakin memicu perkembangan kawasan kearah industrialisasi, artinya semakin menekan penggunaan lahan untuk sawah. Faktor tekanan lahan urban oleh penggunaan lahan modern perkotaan ini selalu terjadi pada banyak wilayah agraris (Hidajatet al., 2013). Untuk Karawang khususnya dan bahkan Indonesia pada umumnya, hal ini bertambah parah dengan lemahnya penegakan hukum (Koran Tempo, 2014). Penegakan hukum dalam konteks penelitian di pedesaan ini adalah pengendalian penggunaan lahan. Penegakan hukum akan berjalan efektif, apabila 5 pilar hukum berjalan baik (Juwana, 2006; Sanjoto, 2008; Manan, 2008), yakni instrumen hukumnya, aparat penegak hukumnya, faktor lingkup masyarakat yang terkena peraturan hukum, faktor kebudayaan atau legal culture, dan fasilitas yang dapat mendukung pelaksanaan hukum. Dalam kondisi saat ini, ke-5 pilar hukum tersebut masih perlu diperbaiki. 


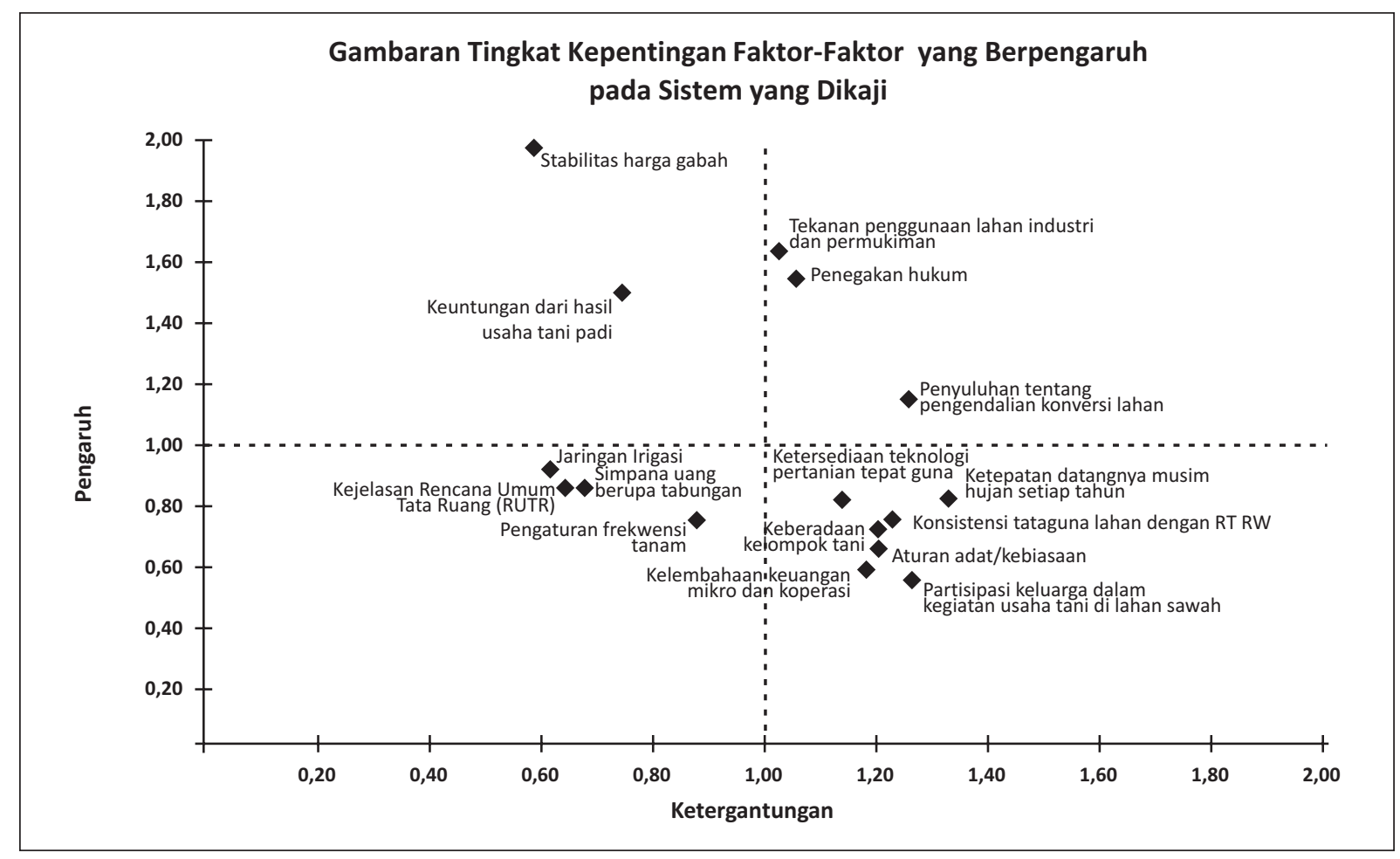

Gambar 5

Diagram Prospektif Faktor Kunci Peningkatan Keberlanjutan

Penggunaan Lahan untuk Sawah di Karawang

Peningkatan pendapatan petani merupakan faktor kunci lain, yang berdasarkan hasil analisis terletak pada kuadran kedua bahwa petani merupakan salah satu bagian masyarakat berpenghasilan rendah atau bahkan miskin, telah banyak dianalisis (Harianto, 2007; Hermawan, 2012). Tulisan ini dengan jelas menunjukkan sangat perlunya petani kita dibantu untuk dapat meningkatkan pendapatannya. Jika tidak, dengan mengingat ketergantungan pangan kita kepada lahan sawah, bahaya penyediaan pangan kedepan akan sangat nyata.

Karena saling terkaitnya faktor tersebut, kebijakannya pun perlu dilakukan secara terpadu. Pada Tabel 5 disajikan kebijakan utama yang hendaknya diprioritaskan untuk peningkatan keberlanjutan penggunaan lahan sawah. Dalam hal penggunaan lahan, penegakan hukum perlu dimulai dari masalah perizinan. Pengetatan perizinan bukan berarti melarang dikeluarkannya izin pembangunan untuk industri, oleh karena industri dan pemukiman faktanya juga merupakan kebutuhan pembangunan, namun pemberian izin perlu benar-benar memperhatikan tata ruang. Wilayah yang sudah ditetapkan dalam RT RW sebagai kawasan pertanian perlu ditaati, demikian pula izin penggunaan lahan untuk industri dan pemukiman dapat diberikan hanya pada wilayah yang peruntukannya urban. Hal ini sekaligus untuk mendorong agar RT RW ditaati. Dewasa ini, Kabupaten Karawang belum menetapkan wilayah Lahan Pertanian Pangan Berkelanjutan (LP2B) sesuai ketentuan UU No. 41/2009, oleh karena itu delineasi dan penetapan LP2B perlu didorong agar segera dilakukan. Bersamaan dengan hal tersebut, pemahaman masyarakat terhadap dampak konversi lahan, terutama bagi keberlanjutan mata pencahariannya perlu ditingkatkan melalui penyuluhan. 
Tabel 5

Kebijakan Prioritas untuk Peningkatan Keberlanjutan Penggunaan Lahan untuk Sawah di Karawang berdasarkanFaktor Kunci Keberlanjutan

\begin{tabular}{l} 
Faktor kunci \\
\hline 1. Tekanan lahan industri dan pemukiman \\
2. Penegakan hukum yang lemah \\
3. Pemahaman masyarakat terhadap konversi \\
lahan \\
4. Stabilitas harga \\
5. Pendapatan dari usahatani
\end{tabular}

Dalam aspek ekonomi, upaya peningkatan pendapatan petani dapat dilakukan dari dua sisi. Di satu sisi, hendaknya petani tidak dibiarkan bersaing sendiri di pasar yang semakin bebas. Peran Pemerintah sebagai regulator dan stabilisator harga beras masih diperlukan, karena itu rivitalisasi terhadap lembaga seperti BULOG perlu dilakukan. Selain itu, subsidi kepada petani perlu ditingkatkan, baik subsidi langsung maupun tidak langsung. Dibandingkan dengan petani lain di seluruh dunia, petani Indonesia relatifkurang beruntung karena rendahnya subsidi di sektor pertanian. Karena itu kedepan, kebijakan yang lebih berpihak kepada petani perlu didorong.

\section{SIMPULAN}

Kondisi saat ini penggunaan lahan untuk sawah di Karawang berada pada status kurang berkelanjutan. Dimensi sosial dan dimensi teknologi mempunyai kinerja cukup berkelanjutan sedangkan dimensi ekonomi, sosial, dan kelembagaan dan hukum menunjukkan kinerja yang kurang berkelanjutan.

Sejumlah atribut dinilai sensitif (leverage attribute) bagi keberlanjutan penggunaan lahan sawah di Karawang. Peningkatan keberlanjutan penggunaan lahan sawah di Karawang dapat dilakukan dengan melakukan intervensi dan perbaikan kinerja, diutamakan pada atribut sensitif. Analisis prospektif terhadap atribut sensitif menemukan faktor kunciuntuk peningkataan keberlanjutan penggunaan lahan sawah. Faktor kunci ini meliputi tekanan dari penggunaan lahan oleh industri dan pemukiman, penegakan hukum yang masih lemah, pemahaman masyarakat terhadap konversi lahan, stabilitas harga beras dan pendapatan dari usahatani. Sejumlah strategi disarankan berdasarkan faktor kunci tersebut, yaitu pengetatan terhadap permohonan izin mendirikan bangunan baru, pelaksanaan rencana tataruang wilayah Kabupaten secara konsisten dan delineasi lahan pertanian pangan berkelanjutan, penyuluhan kepada masyarakat, revitalisasi peran BULOG,pemberian insentif kepada petani dan bantuan modal usaha.

\section{UCAPAN TERIMAKASIH}

Terimakasih disampaikan kepada Direktorat Jenderal Pendidikan Tinggi, Kementerian Pendidikan Nasional yang membiayai penelitian ini melalui Bantuan Operasional Perguruan Tinggi Negeri (BOPTN), Institut Pertanian Bogor, melalui skema Penelitian Unggulan Perguruan Tinggi (PUPT). Terimakasih juga disampaikan kepada Dinas Pertanian, Kehutanan dan Perkebunan Kabupaten Karawang untuk asistensi dalam penelitian lapangan dan fasilitasi dalam Focus Group Discussion. Makalah ini telah disajikan secara oral dalam Seminar Nasional Pengarusutamaan Lingkungan dalam Pengelolaan Sumberdaya Alam di Bogor pada 6 November 2014 dan mendapat banyak masukan, tetapi 
makalah tidak dimasukkan dalam Prosiding Seminar dengan maksud agar dapat dimuat sepenuhnya pada Jurnal ini.

\section{DAFTAR PUSTAKA}

Abdurachman, A., Wahyunto, dan R. Shofiyati. 2005. Kriteria Biofisik dalam Penetapan Lahan Sawah Abadi di Pulau Jawa. Jurnal Litbang Pertanian, 24(4): 131-136.

Alder, J., T.J. Pitcher, D. Preikshot, K. Kaschner, dan B. Ferriss. 2000. How Good Is Good?: A Rapid Appraisal Technique For Evaluation of The Sustainability Status of Fisheries of The North Atlantic. Sea Around Us Methodology Review: 136-182.

Badan Litbang Pertanian. 2015. Produk Badan Penelitian dan Pengembangan Pertanian. http://eproduk.litbang. pertanian.go.id/. 20 Januari 2015 (15:41).

Badan PusatStatistik. 2010.Penduduk Indonesia Menurut Provinsi 2010. http:/ / www. bps.go.id, 20 Januari 2015 (15:40).

Badan Pusat Statistik. 2013. Jawa Barat dalam Angka Tahun 2013. Badan Pusat Statistik Kabupaten Karawang. Karawang.

Badan Pusat Statistik. 2014.Luas Panen Produktivitas - Produksi Tanaman Padi Seluruh Provinsi. http://www.bps. go.id/.20 Desember (21:33).

Bourgeois, R., and F. Jesus. 2004. Participatory Prospective Analysis, Exploring and Anticipating Challenges with Stakeholders. Center for Alleviation of Poverty through Secondary Crops Development in Asia and The Pacific,French Agricultural Reasearch Center for Internasional Development Monograph 46:1- 29.

Braimoh, A.K., dan M. Osaki. 2010. Land Use Change and Environmental Sustainability. Sustainable Science 5: 5-7.

European Commission. 2010. Europeans, agriculture and the common agricultural policy. Eurobarometre, Brussels, Directorate General of Agriculture and Rural Development.

Fauzi, A., dan A. Oxtavianus. 2014. Pengukuran Pembangunan Berkelanjutan di Indonesia. Jurnal Mimbar 30(1): 42-52.

Fauzi, A., dan S. Anna. 2005. Pemodelan Sumberdaya Perikanan dan Kelautan untuk Analisis Kebijakan. Gramedia Pustaka, Jakarta.

Fisheries Com. 1999. Rapf.ish Project. http:/ fisheries.com/project/rapfish.htm. 27 Juli 2014 (15:45).

Fisheries Centre. 2002. Rapid Appraisal of The Status of Fisheries - RAPFISH. 1993-2000 Fisheries Centre Report, Updated to March 2002, Fisheries Centre, University of British Columbia. Vancouver, BC, Canada

Food and Agricultural Organization. 2011. Selected indicators of Food and Agricultural Development in the AsiaPacific Region 2000-2010. Food and Agricultural Organization, Regional Office for Asia and The Pacific, Bangkok, RAP Publication 2011/21.

Godet, M.1999. Scenarios and Strategies: A. Toolbox for Scenario Planning. Librairie des Arts et Matiers. Paris, France.

Harianto. 2007. Peranan Pertanian dalam Ekonomi Pedesaan. Seminar Nasional Dinamika Pembangunan Pertanian dan Pedesaan: Mencari Alternatif Arah Pengembangan Ekonomi Rakyat, Pusat Analisis Sosial Ekonomidan Kebijakan Pertanian. Kementrian Pertanian, Bogor. 4 Desember 2007:112-121.

Hartrisari. 2007. Sistem Dinamik: Konsep Sistem dan Pemodelan untuk Industri dan Lingkungan. SEAMEO BIOTROP. Bogor.

Hermawan, I. 2012. Analisis Eksistensi Sektor Pertanian terhadap Pengurangan Kemiskinan di Pedesaan dan Perkotaan. Jurnal Mimbar 28(2): 135-144. 
Hidajat, J.T., S.R.P. Sitorus, E. Rustiadi, dan Machfud. 2013. Detection of Urban Expansion in Urban Fringe of Jakarta Metropolitan Area Using Landsat TM Image. Proceeding $34^{\text {th }}$ Asian Conference on Remote Sensing Bali.2024 Oktober: (SC04) 566-571.

Hou, J., P. Zhang, X. Yuan, dan Y. Zheng. 2011. Life Cycle Assessment of Biodiesel from Soybean, Jatropha and Microalgae in China Conditions. Renewable and Sustainable Energy Reviews 15(9): 5081-509.

Juwana, H. 2006. Penegakan Hukum dalam Kajian Law and Development: Problem dan Fundamen bagi Solusi di Indonesia.Indonesian Journal of International Law 3(2): 212-220.

Kavanagh, P. 2001. Rapid Appraisal of Fisheries (Rapfish) Project. Rapfish Software Description (for Microsof Exel). Fisheries Centre, University of British Columbia. Vancouver, BC, Canada.

Kim, T.C., U.S. Gim, J.S. Kim, dan D.S.Kim. 2006. The Multi Functionality of Paddy Farming in Korea. Paddy Water Environment 4: 169-179.

Kompas. 2015. Kinerja Hukum Mengecewakan. Kompas, 30 Januari 2015, Halaman 3. Jakarta.

Koran Tempo. 2014. LBH Menilai Penegakan Hukum dan HAM Masih Lemah. 26 Desember 2014. http://koran. tempo.co/. 21 Januari (20:44).

Manan, B. 2008. Konsistensi Pembangunan Nasional dan Penegakan Hukum. Varia Peradilan XXIII (275): 7-13.

Munasinghe, M.1993. Environmental Economic and Sustainable Development. The International Bankfor Reconstruction and Development/The World Bank. Washington DC 20433, USA.

Nzila, C., J. Dewulf, H. Spanjers, D. Tuigong, H. Kiriamiti, dan H. Langenhove. 2012. Multi Criteria Sustainability
Assessment of Biogas Production in Kenya. Applied Energy 93: 496-506.

Panichelli, L., A. Dauriat, dan E. Gnansounou. 2009. Life Cycle Assessment of Soybean-based Biodiesel in Argentina for Export.International Journal of Life Cycle Assessment 14(2): 144-159.

Pitcher, T.J.,dan D.B. Preikshot. 2001. Rapfish: A Rapid Appraisal Technique to Evaluate the Sustainability Status of Fisheries.Fisheries Research 49(3): 255270.

Pitcher, T.J., M.E. Lam, C. Ainsworth, A. Martindale, K. Nakamura, R.I. Perry, dan T. Ward. 2013. Improvements to Rapfish: A Rapid Evaluation Technique for Fisheries Integrating Ecological and Human Dimensions. Journal of Fish Biology 83(4): 865-889.

Pollock, C., J. Pretty, I. Crute, C. Leaver, dan H. Dalton. 2008. Introduction Sustainable Agriculture. Philos Trans R Soc B. 363: 445-446.

Robert, C.P., dan G. Casella. 2004. Monte Carlo Statistical Methods. Second edition. Springer. New York.

Salazar-Ordonez, M., M. Rodriguez-Entrena, dan S. Sayadi. 2013. Agricultural Sustainability from a Societal View: An Analysis of Southern Spanish Citizens.J Agric Environ Ethics 26: 473-490.

Sanjoto, 2008. Penegakan Hukum di Indonesia. Jurnal Dinamika Hukum 8(3): 199-204.

Sikdar, S.K. 2012. Measuring Sustainability. Clean Technology and Environmental Policy 14: 153-154.

Simkova, E. 2012.Rural Development - The Rural Areas Sustainability Indicators. International Journal of Geology 4(6): 106-114.

Stoeglehner, G.,dan M. Narodoslawsky. 2009. How Sustainable Are Biofuels? Answers and Further Questions 
Arising from an Ecological Footprint Perspective. Bioresource Technology 100(16): 3825-3830.

Susilowati, S.H., A.R. Sumaryanto, S. Nurmanaf, R.N. Friyatno, H. Suhaeti, C. Tarigan, N.K. Muslim, dan Agustin. 2008. Arah Perubahan Penguasaan Lahan dan Tenaga Kerja Pertanian. Pusat Analisis Sosial Ekonomi dan Kebijakan Pertanian, Departemen Pertanian. Jakarta.

Swastika, D.K.S., J. Wargiono, Soejitno, dan A. Hasanuddin. 2007. Analisis Kebijakan Peningkatan Produksi PadiMelalui Efisiensi Pemanfaatan Lahan Sawahdi Indonesia.Analisis Kebijakan Pertanian 5(1): 36-52.

Undang-Undang Republik Indonesia Nomor 41 Tahun 2009 Perlindungan Lahan Pertanian Pangan Berkelanjutan. Lembaran Negara Republik Indonesia Tahun 2009 Nomor 149. Jakarta.

United Nations. 2007. Indicators of Sustainable Development: Guidelines and Methodologies. Third Edition. United Nations Publication, Sales No. E.08.II.A.2.

Widiatmaka, K. Munibah, dan I. Firmansyah. 2014.Pencapaian 2 Tahun Penelitian Perencanaan Tataguna Lahan di Wilayah Sentra Produksi Pangan dengan Tekanan Perubahan Penggunaan Lahan
Tinggi (Studi Kasus Kab. Karawang) Menggunakan Skema Penelitian BOPTN IPB. Seminar Hasil-hasil Penelitian LPPM IPB. 9 Desember 2014: 1-13.

Widiatmaka, W. Ambarwulan, danK. Munibah. 2013. Landuse Change During A Decade As Determined By Landsat Imagery Of A Rice Production Region and Its Implication to Regional Contribution to Rice Self Sufficiency: Case Study of Karawang Regency, West Java, Indonesia. Proceeding $34^{\text {th }}$ Asian Conference on Remote Sensing 2013 Bali. 2024 Oktober 2013: (SC04) 834-840.

World Commission on Environment and Development. 1987. Our Common Future. Oxford University Press. New York.

Wu, W., R. Shibasaki, P. Yang, H. Tang, dan K. Sugimoto. 2010. Modeling Changes in Paddy Rice Sown Areas in Asia. Sustainable Science 5: 29-38.

Yoon, C.G. 2009. Wise Use of Paddy Rice Fields to Partially Compensate for The Loss of Natural Wetlands. Paddy Water Environment 7: 357-366.

Zhou, J., Z.K. Erdal, P.T. McCreanor, dan F. Montalto. 2010. Sustainability. Water Environment Research 82 (10): 13761395. 